\title{
PERANCANGAN DAN PENGUKURAN KINERJA PERUSAHAAN BERBASIS KERANGKA AGRI-FOOD SUPPLY CHAIN
}

\author{
Bibit Satriono*, Anggriani Profita, Farida Djumiati Sitania \\ Program Studi Teknik Industri, Fakultas Teknik, Universitas Mulawarman, Samarinda \\ Email: satrionosattok@gmail.com; anggi.profita@yahoo.com; ida.sitania@gmail.com
}

Artikel masuk : 16-07-2020

Artikel direvisi : 09-11-2020

Artikel diterima : 18-11-2020

*Penulis Korespondensi

\begin{abstract}
Abstrak -- Sandia Bakery merupakan usaha pembuatan aneka macam roti manis. Selama menjalankan usahanya, belum pernah melakukan pengukuran kinerja untuk mengetahui tingkat pencapaian tujuan perusahaan. Penelitian ini bertujuan untuk mengetahui kinerja perusahaan, menentukan KPI yang menjadi prioritas utama untuk dilakukan perbaikan, dan memberikan usulan perbaikan. Pengukuran kinerja menggunakan kerangka Agri-Food Supply Chain yang digunakan untuk mengukur kinerja produk hasil olahan pangan. Pada kerangka dilakukan perancangan Key Performance Indicator (KPI) yang sesuai dengan perusahaan. Analisis penelitian menggunakan metode Analytical Network Process (ANP), Importance Performance Analysis (IPA), dan Root Cause Analysis (RCA). Pada tahap perancangan terdapat $16 \mathrm{KPI}$ yang digunakan dalam pengukuran kinerja. Data yang didapatkan tiap KPI diolah dengan Snorm de Boer untuk menyamakan nilai KPI. Metode ANP digunakan untuk mengetahui bobot kepentingan dari KPI menggunakan software Super Decision. Nilai kinerja yang didapatkan adalah 55,702 (Average). Metode IPA digunakan untuk menentukan prioritas KPI yang harus diperbaiki yaitu KPI 15 (promosi) dengan bobot 0,154247 dan skor 28 serta KPI 16 (kecacatan bahan baku) dengan bobot 0,103290 dan skor 48. Metode RCA digunakan untuk menentukan akar permasalahan dari KPI dan memberikan usulan perbaikan. Usulan perbaikan KPI 15 yaitu sales menawarkan produk langsung kepada konsumen, mencoba media sosial berupa Instagram, dan penambahan varian rasa. Usulan perbaikan KPI 16 yaitu produk dari supplier diperiksa secara menyeluruh, diberi penanda untuk tepung lama dan baru, serta diberikan tempat khusus.
\end{abstract}

Kata kunci: Kinerja Perusahaan; Agri-food Supply Chain; Analytical Network Process; Importance Performance Analysis; Root Cause Analysis

\begin{abstract}
Sandia Bakery is a business of making various kinds of sweet bread. While running his business, he has never done a performance measurement to determine the achievement of company goals. This study aims to determine the company's performance, select the KPls that are the top priority for improvement, and provide recommendations for improvements. Performance measurement uses the Agri-Food Supply Chain framework, which is used to measure processed food products' performance. In the framework, a Key Performance Indicator (KPI) is designed according to the company. The research analysis used the Analytical Network Process (ANP) method, Importance Performance Analysis (IPA), and Root Cause Analysis (RCA). At the design stage, there are $16 \mathrm{KPIs}$ that are used in performance measurement. The data obtained by each KPI is processed with Storm de Boer to equalize the KPI value. ANP method is used to determine the weight of importance of KPI using Super Decision software. The performance value obtained is 55,702 (Average). The IPA method is used to determine KPIs' priority that must be improved, namely KPI 15 (promotion) with a weight of 0.154247 and a score of 28 and KPI 16 (raw material defects) with a weight of 0.103290 and a score of 48 . The RCA method is used to determine the root cause of the KPI and provide improvement suggestions. The proposed improvement for KPI 15 is sales offering products directly to consumers, trying social media in the form of Instagram, and adding flavors. The proposal for KPI 16 is that products from suppliers are thoroughly inspected, marked for old and new flour, and given a special place.
\end{abstract}

Keywords: Company Performance; Agri-food Supply Chain; Analytical Network Process; Importance Performance Analysis; Root Cause Analysis 


\section{PENDAHULUAN}

Seiring dengan perkembangan zaman dan teknologi yang sangat pesat, maka persaingan dalam dunia industri juga menjadi semakin ketat. Semakin banyaknya pilihan yang terdapat di pasar membuat konsumen menjadi semakin kritis. Oleh karena itu, perusahaan dituntut untuk menjadi lebih kreatif dalam mengimplementasikan strateginya sehingga dapat menghasilkan produk barang atau jasa yang lebih berkualitas, murah, cepat, dan dapat menarik minat konsumen. Perusahaan perlu melakukan perbaikan baik pada internal perusahaan maupun dengan pihak eksternal (stakeholder) yang terlibat seperti supplier, manufacturer, dan distributor. Kegiatan yang dilakukan stakeholder harus bersinergi satu sama lain sehingga perusahaan dapat menciptakan keunggulan bersaing demi mendapatkan laba dan kepuasan pelanggan.

Selama 30 tahun terakhir yaitu sejak pertama kali rantai pasok (supply chain) dikemukakan pada tahun 1982, keunggulan optimasi dan integrasi rantai pasok menjadi fokus dari berbagai perusahaan besar di dunia. Salah satu aspek fundamental dalam Supply Chain Management (SCM) adalah manajemen kinerja dan perbaikan secara berkelanjutan (Pujawan \& Mahendrawathi, 2010). Cara yang dilakukan oleh perusahan untuk mengetahui bagaimana kinerja mereka serta sektor mana yang masih memerlukan perbaikan adalah dengan melakukan pengukuran kinerja. Meski demikian, walaupun telah menjadi fokus dari berbagai perusahaan besar di dunia, SCM belum terlalu diperhatikan oleh usaha-usaha kecil dan menengah terutama dalam hal pengukuran kinerja.

Sandia Bakery merupakan usaha pembuatan aneka macam roti manis yang terletak di Desa Panca Jaya, Kecamatan Muara Kaman, Kutai Kartanegara. Selama menjalankan usahanya, Sandia Bakery telah membentuk sebuah rantai pasok yang berawal dari supplier hingga konsumen. Akan tetapi, selama ini Sandia Bakery belum pernah melakukan pengukuran kinerja. Sehingga sejak awal berdirinya usaha yakni pada tahun 2013 Sandia Bakery belum mengetahui nilai kinerja dari perusahaan sehingga mengakibatkan perusahaan sulit untuk mengevaluasi dan meningkatkan kinerjanya. Seperti yang dinyatakan oleh Pratiwi, tidak sedikit dari perusahaan-perusahaan berskala kecil dan menengah (UKM) tidak pernah melakukan penilaian terhadap kinerja bisnisnya, sehingga daya saing di tingkat pasar domestic maupun internasional tergolong rendah (Aspriyati et al., 2017). Terlebih lagi untuk produk roti yang dijual oleh Sandia Bakery adalah roti dengan daya tahan produknya tidak lama yaitu satu minggu dengan pemasaran ke beberapa daerah yakni Muara Kaman, Kota Bangun, Sebulu, Separi, dan Tenggarong Seberang. Berdasarkan kondisi ini, perusahaan harus sangat memperhatikan kinerja dari perusahaan untuk dapat mempertahankan kualitas dan meningkatkan kinerja perusahaan agar menjadi lebih baik.

Roti memiliki karakteristik yang tidak tahan lama (perishable) maka diperlukan sistem pengukuran kinerja yang sesuai. Berdasarkan data pada lembar fakta statistik perdagangan agrifood Uni Eropa dan Amerika Serikat pada tahun 2014 - 2018, roti termasuk dalam produk agrifood pada kategori persiapan makanan (food preparation). Pada produk hasil olahan pangan telah terdapat kerangka pengukuran kinerja yang digagas oleh Aramyan et al. (2007) yaitu kerangka Agri-food Supply Chain (AFSC) dengan studi kasus tomat dan hasil pertanian (Profita \& Rahayu, 2018). Kerangka inilah yang menjadi dasar dalam melakukan penelitian pada Sandia Bakery. Kerangka ini sebelumnya telah digunakan dalam penelitian Bourlakis et al. (2014) yang meneliti tentang pengukuran kinerja UKM makanan berdasarkan ukurannya (mikro, kecil, dan menengah). Pengukuran kinerja dilakukan dengan mengadaptasi kerangka AFSC menghasilkan lima kategori utama yaitu konsumsi, fleksibilitas, responsif, kualitas produk, dan total rantai pasokan (Aramyan et al., 2007). Sedangkan pada penelitian ini terdapat 5 kategori yang digunakan yaitu efisiensi, fleksibilitas, responsif, kualitas produk, dan produksi \& distribusi. Berdasarkan kerangka tersebut kemudian ditentukan Key Performance Indicator (KPI) yang sesuai dengan perusahaan untuk digunakan dalam pengukuran kinerja.

Pengukuran kinerja perusahaan tidak hanya menggunakan kerangka pengukuran kinerja AFSC tetapi juga menggunakan metode Analytical Network Process (ANP). Metode ANP digunakan mengetahui nilai tingkat kepentingan yang digunakan dalam melakukan pengukuran kinerja (Prasetyo \& Yuliawati, 2018). Prioritas bobot dari semua KPI pada matriks limit dinormalkan menjadi satu untuk masing-masing kluster. Selain itu digunakan beberapa metode lain dalam menganalisis kinerja yaitu Importance Performance Analysis (IPA) dan Root Cause Analysis (RCA). IPA digunakan untuk menentukan atribut yang harus diperbaiki sesuai dengan urutan prioritasnya (Ramadhan et al., 2013). RCA digunakan untuk mengatasi permasalahan pada KPI dan membantu dalam pemberian usulan strategi kepada Sandia Bakery dalam memperbaiki kinerjanya. RCA memiliki banyak teknik yang dapat digunakan salah 
satunya adalah diagram fishbone untuk menemukan akar permasalahan (Kumara et al., 2019). Penelitian ini bertujuan untuk perusahaan mengetahui kinerjanya perusahaan, menentukan KPI yang menjadi prioritas utama untuk dilakukan perbaikan, dan memberikan usulan perbaikan sehingga dapat meningkatkan kinerjanya.

\section{METODE PENELITIAN}

Penelitian dilakukan pada usaha roti Sandia Bakery pada bulan Oktober 2019 sampai November 2019 di Desa Panca Jaya, Kecamatan Muara Kaman, Kutai Kartanegara. Metode penelitian dibagi dalam beberapa tahapan. Tahapan pertama adalah melakukan wawancara kepada pemilik usaha Sandia Bakery untuk mengetahui kondisi terkini tentang Sandia Bakery dan menentukan KPI yang sesuai dengan kondisi perusahaan sesuai dengan kerangka AFSC. Langkah-langkah yang digunakan untuk model pengukuran kinerja berdasarkan penelitian Ferreira \& Arantes (2015)

Pemodelan rantai pasokan dimulai dengan studi rantai pasokan untuk memahami aliran, pemangku kepentingan dan kekhasannya. Pemodelan rantai pasok pada Sandia Bakery dilakukan dengan cara melakukan wawancara kepada pemilik usaha untuk mengetahui rantai pasok perusahaan (Gambar 1).

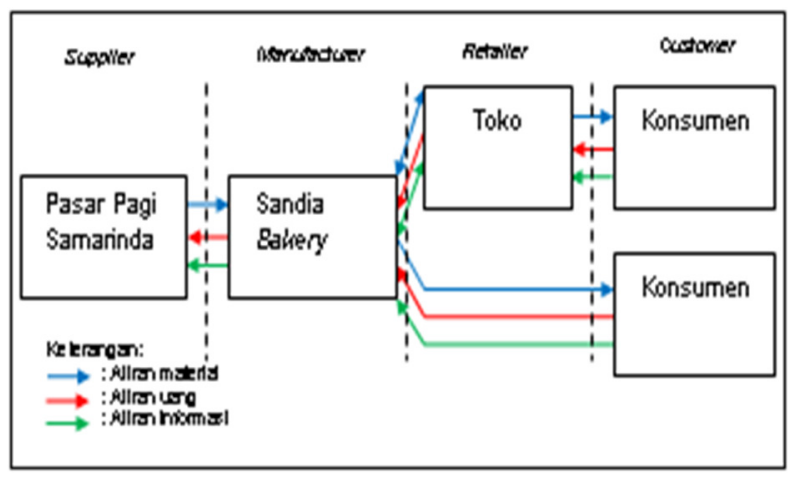

Gambar 1. Rantai Pasok Sandia Bakery

Rantai pasok Sandia Bakery terdiri dari supplier (pasar pagi samarinda), manufacturer (Sandia Bakery), retailer (toko), dan customer (konsumen). Terdapat 3 aliran pada rantai pasok ini yaitu aliran material, uang dan informasi. Sandia Bakery memberikan informasi kepada supplier mengenai bahan baku yang dipesan. Supplier mengirimkan bahan baku dan Sandia Bakery melakukan pembayaran. Sandia Bakery memproduksi roti yang akan didistribusikan ke toko atau konsumen secara langsung. Jumlah roti yang disiapkan untuk toko sesuai dengan informasi permintaan dari toko tersebut. Sandia Bakery juga memberikan informasi mengenai jadwal pengiriman pada tiap toko. Jika terdapat produk yang rusak maka Sandia Bakery akan menggantinya dengan produk baru. Selanjutnya konsumen akan membeli roti yang ada di toko atau langsung ke Sandia Bakery dan memberikan informasi permintaan dari tiap konsumen,

Indikator yang dipilih harus sesuai untuk masing-masing organisasi atau perusahaan dan harus terkait dengan tujuan organisasi atau perusahaan. Penentuan indikator dilakukan dengan melakukan wawancara kepada pemilik usaha. Penelitian ini menggunakan data berupa data biaya produksi, keuntungan, penggunaan tepung, kepuasan pelanggan, jumlah pemesanan tepung, jumlah produksi, waktu produksi, waktu penggantian produk rusak, waktu pengiriman, jumlah keluhan pelanggan, produk terjual, produk cacat, produk kembali, umur simpan, promosi, dan kecacatan tepung. Metode yang dapat digunakan untuk mengumpulkan data adalah wawancara dan pengisian kuesioner oleh pemilik usaha. Wawancara digunakan untuk mencari data yang diperlukan untuk tiap indikator. Wawancara dilakukan dengan mekanisme semi terbuka, dimana pertanyaan sudah tersusus, tapi masih ada kemungkinan jawaban lain dari narasumber. Kuesioner yang digunakan adalah kuesioner perbandingan berpasangan untuk mendapatkan data tingkat kepentingan tiap indikator dengan skala 1-9.

Kesulitan utama dalam menjumlahkan indikator ke dalam indeks kinerja rantai pasokan adalah kenyataan bahwa indikator dapat dinyatakan dalam unit yang berbeda. Normalisasi berfungsi untuk menyamakan satuan tiap indikator. Normalisasi yang digunakan menggunakan persamaan Snorm De Boer. Langkah selanjutnya adalah melakukan perhitungan bobot setiap dimensi dan total kinerja. Perhitungan bobot menggunakan metode ANP dengan bantuan software Super Decision. Nilai total kinerja dapat dihitung dengan cara mengalikan nilai normalisasi dengan nilai bobot tiap KPI. Tingkat parameter ukuran kinerja dapat dilihat pada Tabel 1 (Ardhanaputra et al., 2019).

Tabel 1. Tingkat Indikator Kinerja

\begin{tabular}{cc}
\hline Nilai & Indikator Kinerja \\
\hline$<40$ & Poor \\
$40-50$ & Marginal \\
$50-70$ & Average \\
$70-90$ & Good \\
$>90$ & Exellent \\
\hline
\end{tabular}

Tahap selanjutnya adalah penggunaan metode IPA. IPA digunakan untuk mengetahui prioritas tiap KPI berdasarkan 4 kuadran yang 
terdapat dalam diagram IPA. Diagram IPA dapat dilihat pada Gambar 2 (Irawati, 2019). Jika terdapat KPI yang berada pada kuadran 4, maka KPI tersebut menjadi prioritas utama untuk segera diperbaiki.

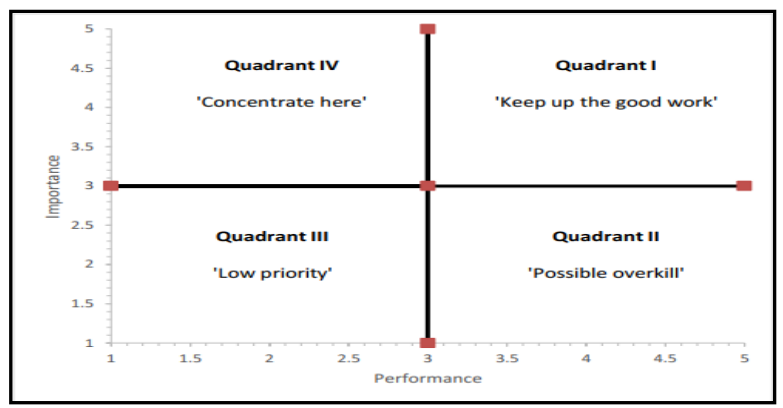

Gambar 2. Diagram IPA

Tahap terakhir adalah penggunaan metode RCA untuk KPI yang berada pada kuadran 4 pada diagram IPA. RCA merupakan salah satu metode dalam continuous improvement dan metode problem solving yang bertujuan untuk mengidentifikasi akar dari suatu permasalahan yang muncul pada sistem atau proses tertentu (Rachmadhani \& Handayani, 2016). Tools yang digunakan dalam Root Cause Analysis adalah diagram Fishbone. Diagram Fishbone atau diagram sebab akibat adalah cara yang efektif secara visual untuk mengetahui kemungkinan penyebab permasalahan tertentu.

\section{HASIL DAN PEMBAHASAN \\ Perancangan KPI}

Berdasarkan kerangka AFSC serta beberapa literatur tambahan tentang $\mathrm{KPI}$, dilakukan wawancara dengan pemilik usaha untuk menentukan KPI yang dapat digunakan untuk menghitung kinerja perusahaan. KPI pada Sandia Bakery dapat dilihat pada Tabel 2.

\section{Perhitungan nilai normalisasi}

Normalisasi dilakukan untuk penyamaan parameter untuk setiap KPI. Perhitungan nilai normalisasi dilakukan menggunakan persamaan Snorm De Boer (Padillah et al., 2016).

Skor $=\frac{(\text { SI }- \text { Smin })}{\text { Smax }- \text { Smin }} \times 100$

SI : Nilai aktual yang berhasil dicapai

Smin : Nilai kinerja terburuk

Smax : Nilai kinerja terbaik

Berdasarkan persamaan tersebut dapat diketahui nilai normalisasi untuk setiap KPI. Rekapitulasi data tiap KPI dapat dilihat pada Tabel 3.
Tabel 2. KPI Sandia Bakery

\begin{tabular}{|c|c|c|c|}
\hline Kriteria & Indikator & Satuan & KPI \\
\hline \multirow{3}{*}{ Efisiensi } & $\begin{array}{l}\text { Biaya } \\
\text { produksi }\end{array}$ & $\begin{array}{l}\text { Rupiah } \\
\text { (Rp) }\end{array}$ & 1 \\
\hline & Keuntungan & $\begin{array}{l}\text { Persen } \\
\text { (\%) }\end{array}$ & 2 \\
\hline & $\begin{array}{l}\text { Penggunaan } \\
\text { bahan baku } \\
\text { (tepung) }\end{array}$ & $\begin{array}{l}\text { Kilogram } \\
\text { (Kg) }\end{array}$ & 3 \\
\hline \multirow{2}{*}{ Fleksibilitas } & $\begin{array}{l}\text { Kepuasan } \\
\text { pelanggan } \\
\text { Jumlah }\end{array}$ & $\begin{array}{l}\text { Persen } \\
(\%)\end{array}$ & 4 \\
\hline & $\begin{array}{l}\text { pemesanan } \\
\text { bahan baku } \\
\text { (tepung) }\end{array}$ & $\begin{array}{l}\text { Karung } \\
(25 \mathrm{Kg})\end{array}$ & 5 \\
\hline \multirow{5}{*}{ Responsif } & $\begin{array}{l}\text { Jumlah } \\
\text { produksi }\end{array}$ & Buah & 6 \\
\hline & $\begin{array}{l}\text { Waktu } \\
\text { produksi }\end{array}$ & Menit & 7 \\
\hline & $\begin{array}{l}\text { Waktu untuk } \\
\text { penggantian } \\
\text { produk rusak }\end{array}$ & Hari & 8 \\
\hline & $\begin{array}{l}\text { Waktu } \\
\text { pengiriman }\end{array}$ & Hari & 9 \\
\hline & $\begin{array}{l}\text { Keluhan } \\
\text { pelanggan }\end{array}$ & Orang & 10 \\
\hline \multirow{4}{*}{$\begin{array}{l}\text { Kualitas } \\
\text { produk }\end{array}$} & $\begin{array}{l}\text { Produk yang } \\
\text { terjual }\end{array}$ & Buah & 11 \\
\hline & $\begin{array}{l}\text { Produk cacat } \\
\text { Jumlah }\end{array}$ & Buah & 12 \\
\hline & $\begin{array}{l}\text { produk } \\
\text { kembali }\end{array}$ & Buah & 13 \\
\hline & Umur simpan & Hari & 14 \\
\hline \multirow[b]{2}{*}{$\begin{array}{l}\text { Produksi \& } \\
\text { Distribusi }\end{array}$} & Promosi & Buah & 15 \\
\hline & $\begin{array}{l}\text { Kecacatan } \\
\text { bahan baku } \\
\text { (tepung) }\end{array}$ & $\begin{array}{l}\text { Karung } \\
(25 \mathrm{Kg})\end{array}$ & 16 \\
\hline
\end{tabular}

Tabel 3. Rekapitulasi Data Normalisasi

\begin{tabular}{ccccc}
\hline KPI & SI & Smax & Smin & Skor \\
\hline KPI 1 & 1316715 & 1598000 & 986000 & 54 \\
KPI 2 & 94 & 96 & 89 & 67 \\
KPI 3 & 21,4 & 26 & 16 & 54 \\
KPI 4 & 99,9 & 100 & 99 & 90 \\
KPI 5 & 11,9 & 12 & 11 & 90 \\
KPI 6 & 774,5 & 940 & 580 & 54 \\
KPI 7 & 363,1 & 360 & 400 & 92 \\
KPI 8 & 5,8 & 7 & 2 & 76 \\
KPI 9 & 1,1 & 1 & 2 & 90 \\
KPI 10 & 0,1 & 0 & 1 & 90 \\
KPI 11 & 727,7 & 906 & 538 & 52 \\
KPI 12 & 1,1 & 0 & 24 & 95 \\
KPI 13 & 45,7 & 30 & 100 & 78 \\
KPI 14 & 6,9 & 7 & 6 & 90 \\
KPI 15 & 98,5 & 356 & 1 & 28 \\
KPI 16 & 2,6 & 0 & 5 & 48 \\
\hline
\end{tabular}




\section{Pembobotan dengan ANP}

Berdasarkan hasil wawancara dan pengisian kuesioner oleh pemilik usaha didapatkan hasil hubungan saling keterkaitan antar KPI. Hubungan keterkaitan tersebut diolah menggunakan software super decision sehingga didapatkan hasil seperti pada Gambar 3.

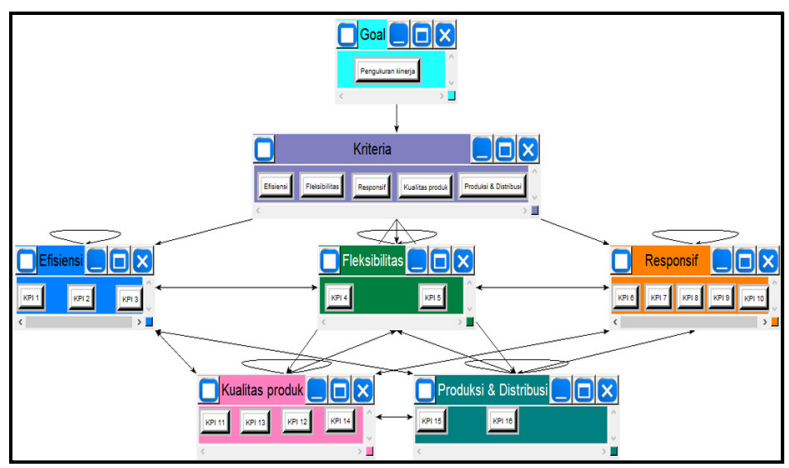

Gambar 3. Model hubungan saling keterkaitan

Setelah didapatkan hubungan saling ketergantungan tiap KPI selanjutnya dilakukan pengisian kuisioner perbandingan berpasangan untuk mendapatkan bobot tiap KPI. Bobot tiap KPI dapat dilihat pada Tabel 4. Hasil pembobotan untuk setiap kriteria dan KPI. Kriteria efisiensi memiliki bobot tertinggi yaitu 0,433 dilanjutkan dengan produksi \& distribusi 0,282 , responsif 0,147 , kualitas produk 0,094 , dan fleksibilitas 0,045 .

Tabel 4. Rekapitulasi Hasil Pembobotan

\begin{tabular}{ccccc}
\hline \multirow{2}{*}{ Kriteria } & \multirow{2}{*}{ Bobot } & \multirow{3}{*}{ KPI } & \multicolumn{2}{c}{ Bobot } \\
& & & Cluster & Limiting \\
\hline \multirow{2}{*}{ Efisiensi } & \multirow{2}{*}{0,433} & 2 & 0,431 & 0,185 \\
& & 3 & 0,243 & 0,104 \\
Fleksibilitas & 0,045 & 4 & 0,392 & 0,140 \\
& & 5 & 0,608 & 0,018 \\
& & 6 & 0,585 & 0,106 \\
Responsif & \multirow{2}{*}{0,147} & 8 & 0,226 & 0,041 \\
& & 9 & 0,048 & 0,009 \\
& & 10 & 0,014 & 0,023 \\
Kualitas & \multirow{2}{*}{0,094} & 11 & 0,490 & 0,042 \\
produk & 12 & 0,101 & 0,009 \\
& & 13 & 0,066 & 0,006 \\
Produksi \& & 0,282 & 14 & 0,343 & 0,029 \\
Distribusi & 0,289 & 0,599 & 0,154 \\
\hline
\end{tabular}

KPI memiliki 2 jenis bobot yaitu cluster dan limiting. Bobot cluster dimaksudkan untuk mengetahui tingkat kepentingan tiap KPI dalam 1 kriteria. Contoh pada KPI 1 pada bobot cluster memiliki nilai tertinggi pada kriteria efisiensi. Sedangkan bobot limiting dimaksudkan untuk mengetahui tingkat kepentingan KPI secara keseluruhan, dimana KPI memiliki bobot tertinggi dari semua KPI dengan nilai 0,185.

\section{Perhitungan nilai kinerja}

Penilaian kinerja perusahaan dapat dihitung dengan mengalikan nilai skor normalisasi tiap KPI dengan nilai bobot dari masing-masing $\mathrm{KPI}$ dan kriteria yang telah didapatkan sebelumnya. Hasil perhitungan nilai akhir KPI dapat dilihat pada Tabel 5. Setelah menentukan nilai akhir untuk setiap KPI, maka langkah selanjutnya adalah melakukan perhitungan untuk nilai total kinerja perusahaan (Tabel 6). Berdasarkan hasil perhitungan untuk nilai total kinerja perusahaan pada Sandia Bakery didapatkan nilai sebesar 55,702 dengan tingkat indikator kinerja termasuk dalam kondisi average (rata-rata).

Tabel 5. Perhitungan Nilai Akhir KPI

\begin{tabular}{cccccc}
\hline Kriteria & KPI & $\begin{array}{c}\text { Skor } \\
(\mathbf{a})\end{array}$ & $\begin{array}{c}\text { Bobot } \\
(\mathbf{b})\end{array}$ & $\begin{array}{c}\text { Nilai } \\
(\mathbf{a} \times \mathbf{b})\end{array}$ & $\begin{array}{c}\text { Total } \\
\text { Nilai }\end{array}$ \\
\hline \multirow{2}{*}{ Efisiensi } & 1 & 54 & 0,431 & 23,280 & \\
& 2 & 67 & 0,243 & 16,351 & 57,227 \\
Fleksi- & 3 & 54 & 0,326 & 17,595 & \\
bilitas & 5 & 90 & 0,392 & 35,424 & 90,151 \\
& 6 & 54 & 0,608 & 54,726 & \\
& 7 & 92 & 0,226 & 20,854 & \\
Responsif & 8 & 76 & 0,048 & 3,665 & 68,803 \\
& 9 & 90 & 0,127 & 11,424 & \\
& 10 & 90 & 0,014 & 1,230 & \\
Kualitas & 11 & 52 & 0,490 & 25,252 & \\
produk & 13 & 95 & 0,101 & 9,659 & 71,025 \\
& 14 & 90 & 0,066 & 5,086 & \\
Produksi & 15 & 28 & 0,343 & 31,028 & \\
\& & & & & \\
Distribusi & 16 & 48 & 0,401 & 19,051 & \\
\hline
\end{tabular}

Tabel 6. Perhitungan Nilai Total Kinerja

\begin{tabular}{|c|c|c|c|}
\hline Kriteria & Skor & Bobot & Nilai \\
\hline Efisiensi & 57,227 & 0,433 & 24,762 \\
\hline Fleksibilitas & 90,151 & 0,045 & 4,060 \\
\hline Responsif & 68,803 & 0,147 & 10,092 \\
\hline $\begin{array}{l}\text { Kualitas } \\
\text { produk }\end{array}$ & 71,025 & 0,094 & 6,681 \\
\hline $\begin{array}{c}\text { Produksi \& } \\
\text { Distribusi }\end{array}$ & 35,905 & 0,282 & 10,108 \\
\hline & 55,702 \\
\hline
\end{tabular}

\section{Importance Performance Analysis (IPA)}

Berdasarkan hasil kinerja didapatkan nilai 55,702 dengan kategori average sehingga kinerja harus ditingkatkan dengan melakukan perbaikan 
terkait KPI yang memiliki nilai rendah. Pengelompokan KPI menggunakan metode Importance Performance Analysis (IPA) berdasarkan skor dan bobot tiap KPI. Skor untuk tiap KPI didapatkan berdasarkan hasil normalisasi dan bobot untuk tiap KPI didapatkan berdasarkan hasil pembobotan pada bobot limiting.

Tabel 7. Skor dan Bobot KPI

\begin{tabular}{ccc}
\hline KPI & Skor & Bobot \\
\hline KPI 1 & 54 & 0,185 \\
KPI 2 & 67 & 0,104 \\
KPI 3 & 54 & 0,140 \\
KPI 4 & 90 & 0,018 \\
KPI 5 & 90 & 0,029 \\
KPI 6 & 54 & 0,106 \\
KPI 7 & 92 & 0,041 \\
KPI 8 & 76 & 0,009 \\
KPI 9 & 90 & 0,023 \\
KPI 10 & 90 & 0,002 \\
KPI 11 & 52 & 0,042 \\
KPI 12 & 95 & 0,009 \\
KPI 13 & 78 & 0,006 \\
KPI 14 & 90 & 0,029 \\
KPI 15 & 28 & 0,154 \\
KPI 16 & 48 & 0,103 \\
\hline
\end{tabular}

Setiap KPI dapat dikelompokkan sesuai prioritas dengan menggunakan metode IPA (Tabel 7). Skor dan bobot yang didapatkan dimasukkan dalam diagram IPA dengan skor menjadi sumbu horizontal dan bobot menjadi sumbu vertikal. KPI dimasukkan kedalam diagram sesuai dengan skor dan bobot masing-masing. Berdasarkan pada diagram IPA (Gambar 4), dapat diketahui tingkat kepentingan dari setiap KPI sebagai berikut:

1. Prioritas Utama (Concentrate Here). KPI yang terdapat pada kuadran ini adalah KPI 15 (promosi) dan KPI 16 (kecacatan bahan baku) yang berarti bahwa kinerja perusahaan pada $\mathrm{KPI}$ ini masih belum memuaskan sehingga perusahaan perlu berkonsentrasi untuk mengalokasikan sumber dayanya guna meningkatkan performa yang masuk pada kuadran ini.

2. Pertahankan Prestasi (Keep Up the Good Work). KPI yang terdapat pada kuadran ini adalah KPI 1, KPI 2, KPI 3, dan KPI 6 yang merupakan faktor penunjang kepuasan konsumen sehingga perusahaan wajib untuk mempertahankan prestasi kinerja tersebut.

3. Prioritas Rendah (Low Priority). Tidak terdapat KPI dalam kuadran ini.

4. Berlebihan (Possibly Overkill). KPI yang terdapat pada kuadran ini adalah KPI 4, KPI 5, KPI 7, KPI 8, KPI 9, KPI 10, KPI 11, KPI 12, KPI 13, dan KPI 14 yang berarti bahwa perusahaan lebih baik mengalokasikan sumber daya yang terkait pada faktor tersebut kepada faktor lain yang lebih memiliki tingkat prioritas lebih tinggi.

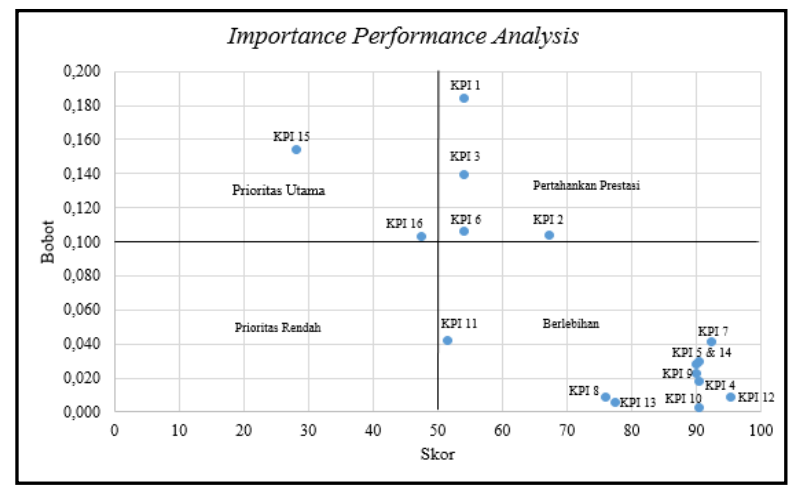

Gambar 4. Diagram IPA

\section{Root Cause Analysis (RCA)}

Berdasarkan hasil pada diagram IPA didapatkan $2 \mathrm{KPI}$ yang harus diperbaiki yaitu KPI 15 (promosi) dan KPI 16 (kecacatan bahan baku). Metode RCA digunakan untuk mengetahui akar permasalahan dari KPI 15 (Gambar 5), dan KPI 16 (Gambar 6).

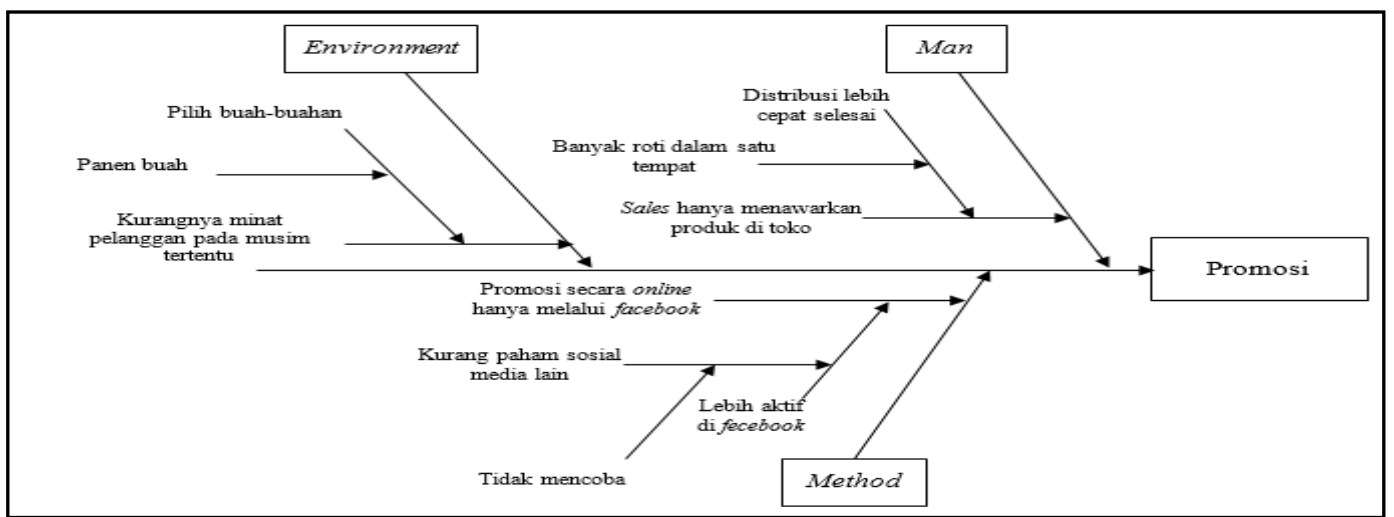

Gambar 5. Diagram Fishbone KPI 15 


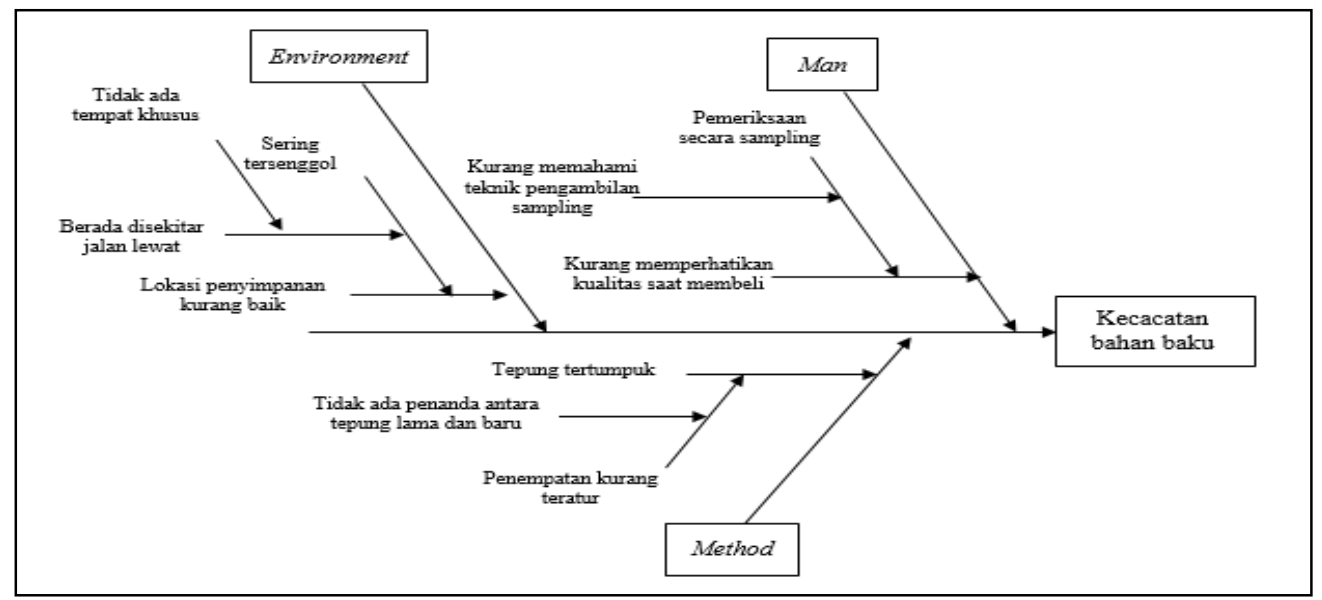

Gambar 6. Diagram Fishbone KPI 16

Berdasarkan hasil diagram fishbone dapat diketahui berbagai akar masalah pada Sandia Bakery sehingga dapat digunakan untuk menentukan usulan perbaikan (Tabel 8).

Tabel 8. Usulan Perbaikan

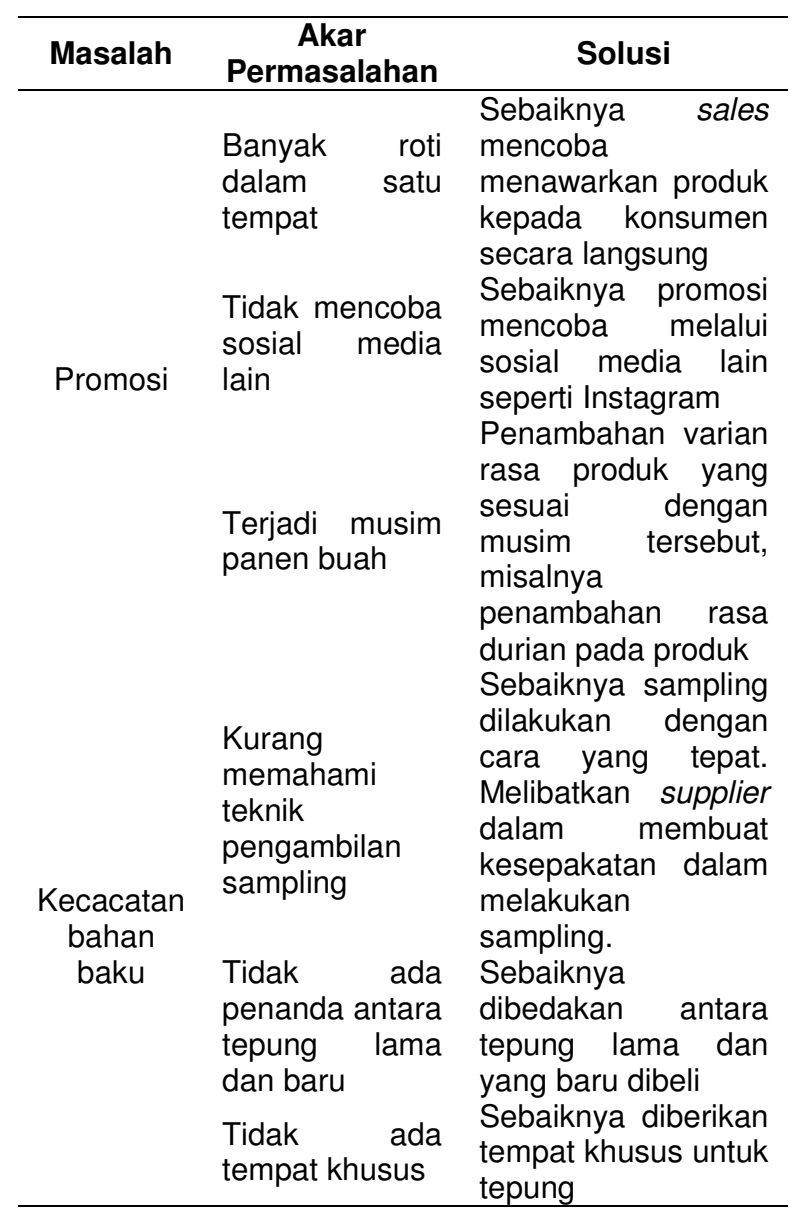

\section{Analisa nilai kinerja}

Nilai kinerja yang didapatkan oleh Sandia Bakery yaitu sebesar 55,702 hanya berbeda sedikit dengan kondisi Marginal yaitu berkisar antara 40 -50. kinerja perusahaan hanya memiliki selisih sedikit dengan kondisi Marginal yaitu sebesar 5,702 sehingga kinerja perusahaan perlu ditingkatkan lagi untuk dapat mencapai kondisi good dengan rentang nilai dari 70 - 90 (Gambar 7). Nilai kinerja tersebut dapat ditingkatkan apabila KPI dengan bobot tinggi juga memiliki skor yang tinggi. Sehingga perusahaan harus memperbaiki KPI dengan bobot tinggi tetapi skor rendah.

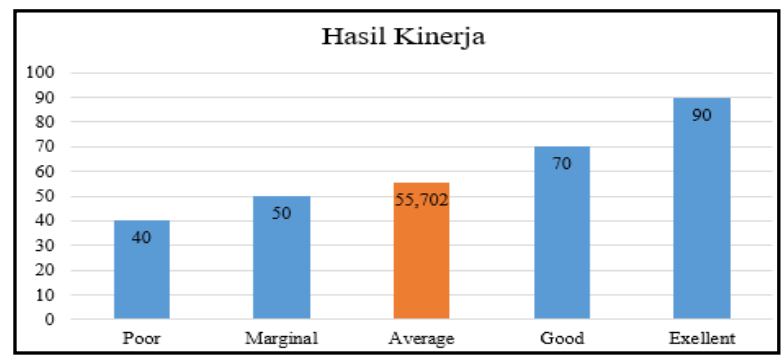

Gambar 7. Grafik Nilai Kinerja

\section{Analisa hasil IPA}

Setiap KPI telah berada pada prioritas masing-masing pada diagram IPA. Kuadran prioritas utama memiliki persentase $12 \%$ karena hanya terdapat $2 \mathrm{KPI}$ dari keseluruhan $16 \mathrm{KPI}$ (Gambar 8). Kedua KPI ini termasuk dalam kategori sistem produksi dengan bobot yang tinggi akan tetapi hanya memiliki skor yang kecil sehingga perusahaan sebaiknya memperbaiki kedua KPI ini secepat mungkin untuk dapat meningkatkan kinerjanya. Kuadran pertahankan prestasi memiliki persentase $25 \%$ karena terdapat $4 \mathrm{KPI}$ yaitu KPI 1, KPI 2, KPI 3, dan KPI 6. Sehingga dapat diketahui bahwa kategori efisiensi pada perusahaan sudah baik karena seluruh KPI efisiensi termasuk dalam kuadran ini dan harus dapat dipertahankan. Kuadran berlebihan 
memiliki persentase $63 \%$ karena terdapat $10 \mathrm{KPI}$ yaitu KPI 4, KPI 5, KPI 7, KPI 8, KPI 9, KPI 10, KPI 11, KPI 12, KPI 13, dan KPI 14. KPI pada kuadran ini memiliki skor tinggi tetapi dengan bobot yang rendah sehingga perusahaan lebih memperhatikan KPI dengan bobot kepentingan yang tinggi karena KPI pada kuadran ini bukan prioritas perusahaan. Persentase kuadran prioritas rendah adalah $0 \%$ karena tidak terdapat KPI pada kuadran ini. Hal ini menunjukkan bahwa tidak ada KPI dengan skor dan bobot yang samasama rendah.

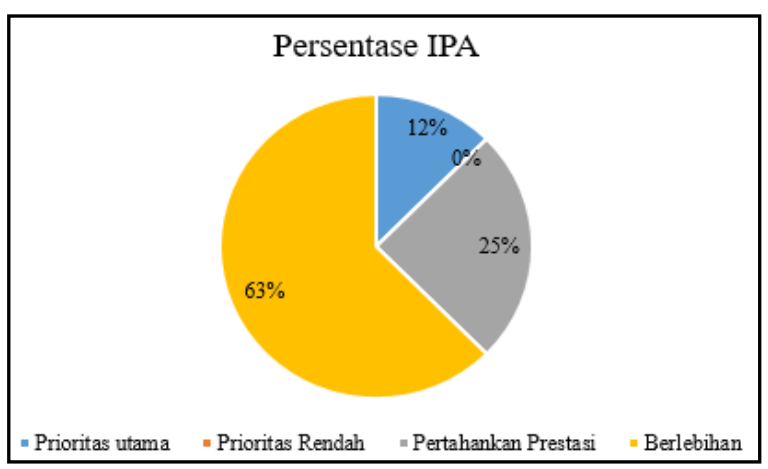

Gambar 8. Persentase diagram IPA

\section{Analisa usulan strategi RCA}

Pada KPI 15 (promosi) terdapat 3 akar permasalahan yaitu dari faktor manusia (man) adalah sales meletakkan banyak roti dalam satu tempat sehingga terdapat usulan sebaiknya sales menawarkan produk kepada konsumen secara langsung. Permasalahan dari faktor metode (method) adalah promosi hanya menggunakan facebook dan tidak mencoba media sosial lain sehingga terdapat usulan sebaiknya dapat mencoba Instagram untuk promosi dan mendapatkan lebih banyak konsumen. Permasalahan dari faktor lingkungan (environment) adalah terjadi musim buah sehingga konsumen lebih memilih buah-buahan yang dimiliki daripada membeli roti. Sehingga diberikan usulan untuk penambahan varian rasa produk seperti rasa durian karena durian memiliki banyak peminat di kalangan masyarakat.

Pada KPI 16 (kecacatan bahan baku) terdapat 3 akar permasalahan yaitu dari faktor manusia (man) adalah kurang memahami teknik pengambilan sampling sehingga sehingga diberikan usulan sebaiknya sebaiknya sampling dilakukan dengan cara yang tepat. Melibatkan supplier dalam membuat kesepakatan dalam melakukan sampling. Permasalahan dari faktor metode (method) adalah tidak ada penanda untuk tepung lama dan baru sehingga menyebabkan tepung lama tertimpa tepung baru dan lama tidak digunakan. Usulan untuk membedakan antara tepung lama dan baru. Permasalahan dari faktor lingkungan (environment) adalah tidak ada tempat khusus untuk tepung sehingga diberikan usulan untuk menyediakan tempat khusus untuk tepung.

Penggunaan metode RCA dalam mengidentifikasi akar permasalahan sesuai dengan penelitian Kumara et al. (2019), bahwa metode RCA tidak hanya mengidentifikasi apa dan bagaimana sebuah event terjadi, melainkan juga mengapa hal itu bisa terjadi sehingga dapat melakukan pencegahan untuk tidak terjadi lagi. Pada KPI 15 (promosi), usulan perbaikan yang diberikan senada dengan hasil penelitian Rahmawati (2019), bahwa promosi dapat dilakukan melalui publikasi iklan atau advertising, personal selling, dan membuat varian baru untuk produk yang dijual. Pada KPI 16 (kecacatan bahan baku, usulan perbaikan senada dengan hasil penelitian Ningsih et al. (2015), bahwa untuk mengurangi kecacatan bahan baku dapat dilakukan dengan mengecek bahan baku secara teliti, penyimpanan bahan baku di tempat yang tepat yaitu tidak panas dan juga tidak lembab, serta mengecek tanggal kadaluarsanya.

\section{KESIMPULAN}

Berdasarkan penelitian yang telah dilakukan, didapatkan total nilai kinerja Sandia Bakery sebesar 55,702 termasuk dalam kategori Average (rata-rata). Terdapat KPI yang menjadi prioritas utama untuk segera dilakukan perbaikan diantaranya adalah KPI 15 (promosi) dengan bobot 0,154247 dan skor 28 serta KPI 16 (kecacatan bahan baku) dengan bobot 0,103290 dan skor 48. Usulan perbaikan untuk KPI 15 dan KPI 16 adalah sebaiknya sales mencoba menawarkan produk kepada konsumen secara langsung, mencoba Instagram untuk promosi, penambahan rasa durian pada produk, pemeriksaan produk dari supplier secara keseluruhan, diberikan penanda untuk tepung, dan disediakan tempat khusus untuk tepung. Penelitian selanjutnya dapat membahas kinerja rantai pasok Sandia Bakery secara keseluruhan dengan melibatkan narasumber dari supplier, retailer, dan konsumen.

\section{DAFTAR PUSTAKA}

Aramyan, L. H., Oude Lansink, A. G. J. M., van der Vorst, J. G. A. J., \& van Kooten, O. (2007). Performance measurement in agri-food supply chains: a case study. Supply Chain Management: An International Journal, 12(4), 304-315. https://doi.org/10.1108/1359854071075982 6

Ardhanaputra, M. I., Ridwan, A. Y., \& Akbar, M. D. (2019). Pengembangan Sistem Monitoring 
Indikator Kinerja Sustainable Production Berbasis Model Supply Chain Operations Reference pada Industri Penyamakan Kulit. JISI: Jurnal Integrasi Sistem Industri, 6(1), 19-28.

https://jurnal.umj.ac.id/index.php/jisi/article/v iew/4062

Aspriyati, W., Andani, A., \& Sukiyono, K. (2017). Pengukuran Kinerja Perusahaan Kopi Bubuk "Sahabat" Di Lubuklinggau: Aplikasi Balanced Scorecard (BSC). Jurnal AGRISEP Kajian Masalah Sosial Ekonomi Pertanian Dan Agribisnis, 16(2), 177-190. https://ejournal.unib.ac.id/index.php/agrisep/ article/view/3033

Bourlakis, M., Maglaras, G., Aktas, E., Gallear, D., \& Fotopoulos, C. (2014). Firm size and sustainable performance in food supply chains: Insights from Greek SMEs. International Journal of Production Economics, 152, 112-130. https://doi.org/10.1016/j.ijpe.2013.12.029

Ferreira, L. M. D. F., \& Arantes, A. (2015). Proposal of a Framework to Assess the Supply Chain Performance in the Agri-food Sector. ICORES, 401-406. https://www.scitepress.org/papers/2015/528 03/52803.pdf

Irawati, N. (2019). Analisis Kepuasan Pengunjung Terhadap Terapan Visitor Management Di Kawasan Candi Prambanan Dengan Metode Importance Performance Analysis. Journal of Tourism and Economic, 2(1), 48-56. https://stieparapi.ac.id/ejurnal/index.php/JT EC/article/view/11

Kumara, W., Rachmadi, A., \& Setiawan, N. Y. (2019). Evaluasi Proses Bisnis Menggunakan Metode Quality Evaluation Framework (QEF)(Studi Kasus: Bali Kencana Bakery). Jurnal Pengembangan Teknologi Informasi Dan IImu Komputer, 3(8), $\quad$ 7779-7785. http:/jptiik.ub.ac.id/index.php/jptiik/article/view/6056

Ningsih, I. K., Surawan, F. E. D., \& Efendi, Z. (2015). Analisis Mutu Fisik Roti Manis Perusahaan Roti Barokah Kota Lahat Physical Quality Analysis Of 'Roti Manis' At Barokah Bakery In Lahat. Agroindustri, 5(1), 20-35.

https://ejournal.unib.ac.id/index.php/agroind ustri/article/view/3880

Padillah, H., Chrisnanto, Y. H., \& Wahana, A. (2016). Model supply chain operation reference (scor) dan analytic hierarchy process (ahp) untuk sistem pengukuran kinerja supply chain managemen. Prosiding SNST Fakultas Teknik, 31-36. https://publikasiilmiah.unwahas.ac.id/index. php/PROSIDING_SNST_FT/article/view/15 05

Prasetyo, A. D., \& Yuliawati, E. (2018). Analisis Performansi Supply Chain Dengan Pendekatan Green SCOR Dan ANP. Prosiding Seminar Nasional Sains Dan Teknologi Terapan, 441-446. https://ejurnal.itats.ac.id/sntekpan/article/vie $w / 323$

Profita, A., \& Rahayu, D. K. (2018). Pengembangan Model Pengukuran Kinerja Agri-Food Supply Chain Berkelanjutan Berbasis Pengelolaan Risiko. Journal of Industrial Engineering Management, 3(2), 32-40.

https://doi.org/10.33536/jiem.v3i2.232

Pujawan, I. N., \& Mahendrawathi, E. R. (2010). Supply chain management. Surabaya: Guna Widya.

Rachmadhani, A. P., \& Handayani, N. U. (2016). Analisis Performansi Penanganan Keluhan Pelanggan Pada Sistem Drop Call Melalui Call-center 147 Menggunakan Value Stream Mapping Studi Kasus Pada PT Telkom Indonesia Tbk. Seminar Nasional Multi Disiplin IImu, 254-263. https://www.unisbank.ac.id/ojs/index.php/se ndi_u/article/view/4186

Rahmawati, D. (2019). Pengembahang Pemasaran Produk Roti dan Pastry dengan Bauran Pemasaran 4P di Sari Good Bakery. Jurnal Abdimas BSI: Jurnal Pengabdian Kepada Masyarakat, 2(1), 233-243. https://ejournal.bsi.ac.id/ejurnal/index.php/a bdimas/article/view/5024

Ramadhan, E. W., Setyanto, N. W., \& Efranto, R. Y. (2013). Analisis Kepuasan Konsumen Terhadap Kualitas Pelayanan Dengan Penerapan Importance Performance Analysis (IPA) Dan Model Kano (Studi Kasus Pada Asrama Mahasiswa Griya Brawijaya Universitas Brawijaya Malang). Jurnal Rekayasa Dan Manajemen Sistem Industri, 1(2), 183-193. http://jrmsi.studentjournal.ub.ac.id/index.php /jrmsi/article/view/26 